\title{
EFEKTIVITAS SISTEM PENDISTRIBUSIAN BERAS BERSUBSIDI UNTUK MASYARAKAT BERPENDAPATAN RENDAH DALAM MENINGKATKAN KESEJAHTERAAN MASYARAKAT DI KELURAHAN TALANG KERAMAT KECAMATAN TALANG KELAPA KABUPATEN BANYUASIN
}

\author{
Oleh: \\ H. Suparman, S. Sos., S. Pd. I., M. Si. \\ Dosen Sekolah Tinggi Ilmu Administrasi Satya Palembang \\ e-Mail: suparmanstia03@gmail.com
}

\begin{abstract}
ABSTRAK
Kebutuhan yang semakin meningkat dan pendapatan masyarakat yang tergolong rendah, membuat sebagian masyarakat merasa kesusahan terutama dalam membeli beras. Tingkat pendidikan kepala rumah tangga yang tidak tamat SD atau hanya sampai tamat SD membuat masyarakat sulit mencari pekerjaan yang mengharuskan bekerja dengan tenaga yang penghasilannya tidak sebanding dengan kebutuhan.Untuk itu, Lurah berperan penting dalam menjalankan program pemerintah yaitu membantu tercapainya sasaran atau tujuan subsidi beras sesuai yang direncanakan. Salah satunya adalah mengatur distribusi subsidi beras hingga bisa sampai ke tangan masyarakat berpendapatan rendah dengan efektif.

Teknik pengumpulan data yang dipergunakan yaitu : teknik observasi, wawancara dan dokumentasi. Dalam penelitian ini penulis menggunkan metode penelitian kualitatif, yaitu penelitian yang dilakukan tanpa membuat perbandingan atau menghubungkan dengan variabel lain.

Hasil analisis data observasi, wawancara dan dokumentasi, maka ditemukan bahwa:

1. Adanya pengaruh lingkungan yaitu cara berfikir masyarakat yang sempit dan kurangnya sosialisasi dari aparat kelurahan serta indikator keberhasilan subsidi beras yang belum sepenuhnya tercapai sehingga bisa dikatakan kurang efektif.

2. Subsidi beras hanya mampu membantu sedikit biaya pengeluaran dan belum mampu meningkatkan kesejahteraan masyarakat untuk pemenuhan kebutuhan dalam bentuk beras.
\end{abstract}

Kata kunci: efektivitas, sistem pendistribusian, dan kesejahteraan masyarakat.

\section{PENDAHULUAN}

Kemiskinan merupakan masalah sosial yang senantiasa hadir di tengah tengah masyarakat, khususnya di negara berkembang seperti Indonesia.Berbagai teori dan pengembangan pun terus menerus di kembang-kan untuk mengatasi kemiskinan ini, karena gejala kemiskinan terus meningkat sejalan 
dengan krisis yang masih dihadapi bangsa Indonesia. Krisis telah membawa Indonesia pada peningkatan angka kemiskinan terutama sebagai efek dari gejolak krisis moneter maka pemerintah menggulirkan berbagai kebijakan di antaranya adalah Bantuan Langsung Tunai (BLT), Kredit Usaha Rakyat (KUR), Jaminan KesehatanMasyarakat (JAMKESMAS), Program Keluarga Harapan, Bantuan Operasional Sekolah (BOS) serta Subsidi Beras bagi Masyarakat Berpendapatan Rendah.

Program subsidi beras adalah salah satu bentuk upaya pemerintah Indonesia untuk meningkatkan kesejahteraan rakyat yang menjadi cita-cita Indonesia yang tertuang dalam Pembukaan Undang-Undang Dasar 1945 alinea keempat, yaitu melindungi segenap tanah air dan tumpah darah Indonesia, memajukan kesejahteraan umum, mencerdaskan kehidupan bangsa, dan ikut melaksanakan ketertiban dunia yang berdasarkan perdamaian abadi dan keadilan sosial.

Peraturan Presiden Republik Indonesia Nomor 15 tahun 2010 ,"Percepatan Penang-gulangan Kemiskinan", Pasal 5 ayat (1) dan Instruksi Presiden Nomor 3 tahun 2010, "Program Pembangunan yang Berkeadilan", diktum kedua. Keluarga penerima manfaat subsidi beras yaitu keluarga yang berpen-dapatan rendah (miskin dan rentan miskin) atau disebut dengan Rumah Tangga Sasaran Penerima Manfaat (RTS-PM).RTS-PM Subsidi beras ditetapkan berdasarkan Pendataan Program Perlindungan Sosial (PPLS-2011) oleh Badan Pusat Statistik (BPS).

Program subsidi beras merupakan salah satu dari berbagai programprogram pro rakyat yang diluncurkan oleh pemerintah Indonesia sebagai upaya percepatan penanggulangan kemiskinan.Berdasarkan data Badan Pusat Statistik (BPS) pada tahun 2016 terdapat 14 kriteria miskin yaitu sebagai berikut :

1. Luas lantai bangunan tempat tinggal kurang dari $8 \mathrm{~m} 2$ per orang.

2. Jenis lantai tempat tinggal terbuat dari tanah atau bambu atau kayu murahan.

3. Jenis dinding tempat tinggal dari bambu atau rumbia atau kayu berkualitas rendah atau tembok tanpa diplester.

4. Tidak memiliki fasilitas buang air besar atau bersama-sama dengan rumah tangga lain.

5. Sumber penerangan rumah tangga tidak menggunakan listrik.

6. Sumber air minum berasal dari sumur atau mata air tidak terlindung atau sungai atau air hujan.

7. Bahan bakar untuk memasak seharihari adalah kayu bakar atau arang atau minyak tanah.

8. Hanya mengkonsumsi daging atau susu atau ayam dalam satu kali seminggu.

9. Hanya membeli satu stel pakaian baru dalam setahun.

10. Hanya sanggup makan sebanyak satu atau dua kali dalam sehari.

11. Tidak sanggup membayar biaya pengobatan di puskesmas atau poliklinik.

12. Sumber penghasilan kepala rumah tangga adalah: petani dengan luas lahan $500 \mathrm{~m} 2$, buruh tani, nelayan, buruh bangunan, buruh perkebunan dan atau pekerjaan lainnya dengan pendapatan dibawah Rp. 600.000,per bulan. 
13. Pendidikan tertinggi kepala rumah tangga: tidak sekolah atau tidak tamat SD atau tamat SD.

14. Tidak memiliki tabungan atau barang yang mudah dijual dengan minimal Rp. 500.000,- seperti sepeda motor kredit atau non kredit, emas, ternak, kapal motor, atau barang modal lainnya.

Subsidi beras untuk masyarakat berpendapatan rendah merupakan subsidi pangan pokok dalam bentuk beras yang diperuntukkan bagi keluarga miskin atau tergolong berpendapatan rendah. Beras merupakan makanan pokok sebagian besar penduduk Indonesia, oleh karena itu pada tahun 2002 pemerintah Indonesia meluncurkan program beras yang merupakan implementasi dari konsistensi pemerintah dalam rangka memenuhi hak pangan masyarakat.

Program subsidi beras merupakan program nasional yang bertujuan untuk membantu memenuhi kecukupan pangan dan mengurangi beban finansial rumah tangga sasaran (RTS) melalui penyediaan beras bersubsidi.Sejak tahun 2007, Menteri Koordinator Kesejahteraan Rakyat (Menko Kesra) menjadi koordinator pelaksana program beras untuk pendistribusian beras, Badan Urusan Logistik (BULOG) bertanggung jawab mendistribusikan dan pemerintah daerah bertanggung jawab menyalurkan beras dari titik distribusi kepada rumah tangga sasaran.

Program ini sebenarnya sudah ada sejak krisis pangan di Indonesia pada tahun 1998 yang dinamakan dengan Operasi Pasar Khusus (OPK). Namun, baru pada tahun 2002 program Operasi Pasar Khusus ini diubah namanya menjadi program beras untuk Rumah Tangga Miskin (Raskin). Pada tahun 2002 pemerintah mengganti nama
Operasi Pasar Khusus (OPK) menjadi program Raskin atau Subsidi beras untuk rumah tangga miskin agar lebih mencerminkan sifat program, yakni sebagai program perlindungan sosial bagi Rumah Tangga Miskin (RTM), tidak lagi sebagai program darurat penanggulangan dampak krisis ekonomi. Pada tahun 2008 menjadi beras bersubsidi untuk masyarakat berpendapatan rendah.Program ini bertujuan untuk mengurangi beban pengeluaran Rumah Tangga Sasaran (RTS) dan mengurangi beban biaya kebutuhan pangan melalui pemenuhan sebagian kebutuhan pokok dalam bentuk beras.

Penetapan jumlah beras per bulan per Rumah Tangga Sasaran (RTS) pada awalnya $10 \mathrm{~kg}$, selama beberapa tahun kemudian bervariasi dari $10 \quad \mathrm{~kg}-20$ kg.Dan pada tahun 2007 kembali menjadi $10 \mathrm{~kg}$. Frekuensi distribusi yang pada tahun 2005 yaitu 12 kali per tahun , pada tahun 2006 berkurang menjadi 10 kali per tahun dan pada tahun-tahun seterusnya sampai tahun 2016 tetap 12 kali per tahun atau sama dengan 1 bulan sekali. Sasaran penerima manfaat yang sebelumnya menggunakan data Keluarga Prasejahtera (KPS) dan Keluarga Sejahtera 1 (KS-1) hasil pendekatan BKKBN.Sejak tahun 2006 hingga saat ini berubah menggunakan data Rumah Tangga Miskin (RTM) hasil Badan Pusat Statistik.

Berdasarkan Pedoman Umum Subsidi Beras untuk Masyarakat Berpendapatan Rendah, masing-masing keluarga miskin akan menerima beras sebesar 15 $\mathrm{Kg} / \mathrm{RTS} /$ bulan atau setara dengan 180 $\mathrm{Kg} / \mathrm{RTS} /$ tahun dengan harga tebus $\mathrm{Rp}$ $1.600,-/ \mathrm{Kg}$. Namun, dalam prakteknya program subsidi beras ini masih belum sesuai harapan karena masih banyak beras yang dibagikan tidak tepat sasaran 
atau warga yang tergolong tidak miskin pun mendapatkan subsidi beras.

Berdasarkan hasil observasi pada tanggal 04 September 2019 di Kelurahan Talang Keramat Kecamatan Talang Kelapa Kabupaten Banyuasin didapatkan informasi terkait distribusi subsidi beras yaitu sebagai berikut:

1. Pembagian Subsidi beras tidak sesuai dengan yang diharapkan warga.

2. Seringkali terjadi keterlambatan dan kenaikan harga beras tanpa pemberitahuan terlebih dahulu.

3. Tidak terlaksananya distribusi subsidi beras dengan jumlah yang telah ditentukan yaitu $15 \mathrm{~kg} / \mathrm{RTS} / \mathrm{bulan}$ sehingga beras yang diterima oleh masyarakat berpendapatan rendah menjadi berkurang dan berarti hak yang diterimanya juga berkurang.

Berdasarkan uraian tersebut di atas, maka peneliti tertarik untuk meneliti dengan judul :"Efektivitas Sistem Pendistribusian Beras Bersubsidi Untuk Masyarakat Berpendapatan Rendah dalam Meningkatkan Kesejahteraan Masyarakat di Kelurahan Talang Keramat Kecamatan Talang Kelapa Kabupaten Banyuasin".

Berdasarkan uraian dari latar belakang, peneliti membuat rumusan masalah sebagai berikut :

a. Bagaimanakah

Efektivitas

Sistem Pendistribusian Beras Bersubsidi Untuk Masyarakat Berpendapatan Rendah dalam Meningkatkan Kesejahteraan Masyarakat di Kelurahan Talang Keramat Kecamatan Talang Kelapa Kabupaten Banyuasin?

b. Faktor-faktor apakah yang menyebabkan kurang Efektifnya Sistem Pendistribusian Beras Bersubsidi Untuk Masyarakat Berpendapatan Rendah dalam Meningkatkan Kesejahteraan Masyarakat di Kelurahan Talang
Keramat Kecamatan Talang Kelapa Kabupaten Banyuasin?

\section{TINJAUAN PUSTAKA}

\section{Pengertian Efektivitas}

Kata efektif berasal dari bahasa Inggris yaitu effective yang berarti berhasil,atau sesuatu yang dilakukan berhasil dengan baik.Konsep efektivitas sesungguhnya merupakan suatu konsep yang luas,mencakup berbagai faktor di dalam maupun di luar organisasi.Konsep efektivitas ini oleh para ahli belum ada keseragaman pandangan, dan hal tersebut dikarenakan sudut pandang yang dilakukan dengan pendekatan disiplin ilmu yang berbeda, sehingga melahirkan konsep yang berbeda pula di dalam pengukurannya. Namun demikian, banyak juga ahli dan peneliti yang telah mengungkapkan apa dan bagaimana mengukur efektivitas itu.

Pencapaian tujuan yang dilakukan dapat dikatakan efektif, kurang efektif,sangat kurang efektif, sampai tidak efektif apabila tujuan tersebut telah dijalankan dan telah dapat dilihat hasilnya.Efektivitas pada dasarnya mengacu pada sebuah keberhasilan atau pencapaian tujuan. Efektivitas merupakan salah satu dimensi dari produktivitas,yaitu mengarah kepada pencapaian untuk kerja yang maksimal, yaitu pencapaiantarget yang berkaitan dengan kualitas, kuantitas dan waktu. Kaitannnya dengan penelitian distribusi subsidi beras untuk masyarakat berpendapatan rendah dapat dipahami bahwaefektivitas dalam proses suatu distribusi subsidi beras tidak dapat mengabaikan targetsasaran yang telah ditetapkan danharus sesuai aturan.

Distribusi subsidi beras untuk masyarakat berpendapatan rendah hendaknya berjalan sesuai rencana dan 
tepat waktu.Efektivitasmerupakan suatu konsep yang sangat penting dalam suatu organisasi karena mampu memberikangambaran mengenai keberhasilan suatu organisasi dalam mencapai sasarannya.

\section{Pengertian Sistem Distribusi Subsidi Beras}

\section{a. Sistem}

Sistem berasal dari bahasa Latin (Systema) dan bahasa Yunani (Sustema) adalah suatu kesatuan yang terdiri dari komponen atau elemen yang dihubungkan bersama untuk memudahkan aliran informasi, materi atau energi untuk mencapai suatu tujuan. Sistem juga merupakan kesatuan bagian-bagian yang saling berhubungan yang berada dalam suatu wilayah serta memiliki item-item penggerak, contoh umum misalnya seperti negara.Negara merupakan suatu kumpulan dari beberapa elemen kesatuan lain seperti provinsi yang saling berhubungan sehingga membentuk suatu negara di mana yang berperan sebagai penggeraknya yaitu rakyat yang berada dinegara tersebut.

Berdasarkan uraian diatas, maka dapat ditarik kesimpulan bahwa Sistem adalah bagian-bagian yang berkaitan satu sama lain untuk melakukan kerjasama dengan cara mengolah data maupun barang dan menghasilkan tujuan yang telah ditetapkan.

\section{b. Distribusi}

Barang hasil produksi tidak mempunyai nilai guna jika tidak sampai ke tangan konsumen atau penerimanya.Kegiatan distribusi adalah kegiatan penyaluran barang dan jasa dari produsen kepada konsumen.Selain pengertian tersebut, distribusi juga merupakan usaha untuk menambah nilai guna suatu barang atau jasa.
Berdasarkan uraian tersebut diatas, distribusi dapat diartikan sebagai suatu proses kegiatan menyalurkan barang dari produsen ke konsumen untuk dipakai ataupun dikonsumsi oleh konsumen tersebut. Pelaku kegiatan distribusi bisa perorangan, bisa juga berbentuk lembaga distribusi atau perantara.Lembaga atau perorangan yang melakukan kegiatan distribusi disebut distributor.

Berdasarkan uraian penjelasan diatas, maka sistem pendistribusian subsidi beras untuk masyarakat berpendapatan rendah adalah bagian-bagian yang berkaitan satu sama lain untuk bekerjasama menyalurkan subsidi beras untuk masyarakat berpendapatan rendah hingga bisa sampai ke tangan rumah tangga sasaran. Kaitannya dengan penelitian ini adalah distribusi subsidi beras untuk masyarakat berpendapatan rendah menjadi tanggung jawab pemerintah daerah dan agar dapat menjadi prioritas dan perhatian aparatur kelurahan mengenai kelancaran distribusi subsidi beras sehingga bisa sampai ke tangan masyarakat yang berpendapatan rendah yang berhak menerimanya.Dalam pedoman umum Beras Bersubsidi untuk Masyarakat Berpendapatan Rendah Tahun 2016 yang tercantumdalam $\mathrm{Bab} 2$, indikator efektivitas pendistribusian subsidi beras di tunjukkan dengantercapainya 6 (enam) target yaitu sebagai berikut:

1. Tepat Sasaran yaitu subsidi beras hanya diberikan kepada rumah tangga sasaran penerima manfaat hasil data Badan Pusat Statistik (BPS) Tahun 2016.

2. Tepat Waktu yaitu waktu pelaksanaan distribusi beras kepada rumah tangga sasaran sesuai dengan rencana distribusi yaitu satu bulan sekali. 
3. Tepat Jumlah yaitu jumlah subsidi beras yang merupakan hak rumah tangga sasaran sesuai dengan ketentuan yang berlaku, yaitu sebanyak $15 \mathrm{~kg} / \mathrm{bulan}$ atau $180 \mathrm{~kg} / \mathrm{tahun}$.

4. Tepat administrasi yaitu terpenuhinya persyaratan administrasi secara benar, lengkap dan tepat waktu.

5. Tepat harga yaitu harga tebus subsidi beras adalah sebesar Rp.1600/kg di titik distribusi.

6. Tepat kualitas yaitu terpenuhinya persyaratan kualitas beras sesuai dengan kualitas beras Badan Urusan Logistik (BULOG).

\section{Pengertian}

Kesejahteraan

\section{Masyarakat}

Kesejahteraan masyarakat atau kesejah-teraan sosial dalam artian yang sangat luas mencakup berbagai tindakan yang dilakukan manusia untuk mencapai tingkat kehidupan masyarakat yang lebih baik.

Menurut Undang-undang Nomor 11 Tahun 2009,"Kesejahteraan Sosial adalah kondisi terpenuhinya kebutuhan material, spiritual dan sosial warga negara agar dapat hidup layak dan mampu mengembangkan diri, sehingga dapat melaksanakan fungsi sosialnya."

Menurut Peraturan Daerah Nomor 3 Tahun 2010, "Gelandangan dan Pengemis menyebut-kan pengertian kesejahteraan sosial yang tertulis dalam pasal 1 yaitu suatu tata kehidupan dan penghidupan sosial baik materil maupun spiritual yang diliputi oleh rasa keselamatan, kesusilaan dan kententraman lahir batin, yang memungkinkan bagi setiap warga negara mengadakan usaha pemenuhan kebutuhan jasmaniah, rohaniah yang sebaik-baiknya bagi diri, keluarga dan masyarakat dengan menjunjung tinggi hak-hak asasi manusia serta tanggung jawab sosial."

Perhatian masyarakat akan taraf hidup yang lebih baik dari warganya diwujudkan dengan penyediaan berbagai bentuk usaha kesejah-teraan sosial yang kongkret. Usaha kesejah-teraan sosial ini mengacu pada program pelayanan dan berbagai kegiatan secara kongkret (nyata) berusaha menjawab kebutuhan masyarakatnya.

Berdasarkan penjelasan uraian di atas mengenai kesejahteraan sosial, maka dapat diambil kesimpulan bahwa kesejahteraan sosial merupakan suatu usaha yang dilakukan untuk meningkatkan taraf hidup manusia yang di dalamnya mencakup pemenuhan kebutuhan hidup. Masyarakat dikatakan sejahtera ketika mereka dapat hidup mandiri, memiliki tempat tinggal yang layak, dapat menjalani kehidupan sebagaimana mestinya seperti dapat bersekolah, beribadah dan juga dalam pemenuhan kebutuhannya. Data Badan Pusat Statistik (BPS) Tahun 2016 tentang kesejahteraan sosial adalah terpenuhinya 5 (lima) indikator mengukur kesejahteraan masyarakat yaitu sebagai berikut:

1. Pendapatan yaitu pendapatan yang dimaksud dalam Keputusan Menteri Sosial Nomor 146 Tahun 2013 yaitu Mempunyai sumber mata pencaharian tetapi tidak mempunyai kemampuan memenuhi kebutuhan dasar.

2. Kesehatan yaitu tidak mampu atau mengalami kesulitan untuk berobat ke tenaga medis kecuali ke puskesmas atau yang disubsidi pemerintah.

3. Pendidikan yaitu pendidikan tertinggi kepala rumah tangga tidak 
sekolah atau tidak tamat $\mathrm{SD}$ atau tamat SD.

4. Jumlah pengeluaran yaitu mempunyai pengeluaran sebagian besar digunakan untuk memenuhi konsumsi makanan pokok dengan sangat sederhana.

5. Keadaan tempat tinggal yaitu mempunyai dinding rumah terbuat dari bamboo atau kayu/tembok dengan kondisi tidak baik atau kualitas rendah, termasuk tembok yang sudah usang atau tidak diplester.

\section{Mekanisme Penyaluran Beras Bersubsidi untuk Masyarakat Berpendapatan Rendah menurut Peraturan Menteri Koordinator Bidang Pembangunan Manusia dan Kebudayaan Republik Indonesia Nomor 1 Tahun 2016}

Peraturan Menteri Koordinator Bidang Pembangunan Manusia dan Kebudayaan Republik Indonesia Nomor 1 Tahun 2016 Tentang Pedoman Umum Subsidi Beras bagi masyarakat berpendapatan rendah tentang Mekanisme Penyaluran Subsidi Beras adalah sebagai berikut:

a. Berdasarkan jumlah alokasi Rumah Tangga Sasaran-Penerima Manfaat Subsidi beras bagi masyarakat berpendapatan rendah, Bupati/Walikota/Ketua Tim Koordinasi subsidi beras bagi masyarakat berpendapatan rendah Kabupaten atau Kota atau pejabat yang ditunjuk oleh Bupati atau Walikota menerbitkan Surat Perintah Alokasi kepada Badan Urusan Logistik.

b. Berdasarkan Surat Perintah Alokasi, Badan Urusan Logistik menerbitkan Surat Perintah Penyaluran Barang atau beras untuk masing-masing kecamatan atau kelurahan tanpa menunggu peluncuran resmi penyaluran subsidi beras bagi masyarakat berpenda-patan rendah pada awal tahun.

c. Sesuai dengan Surat Perintah Penyaluran Barang maka Badan Urusan Logistik menyalurkan beras sampai ke titik distri-busi, termasuk apabila terjadi penggantian beras.

d. Sebelum penyaluran dilakukan, dapat dilakukan pengecekan kualitas beras oleh Tim Koordinasi Subsidi beras bagi masyarakat berpendapatan rendah atau pelaksana distribusi di gudang Perum Badan Urusan Logistik dan dibuktikan dengan berita acara yang ditandatangani oleh Perum Badan Urusan Logistik dan Tim Koordinasi Subsidi beras bagi masyarakat berpendapatan rendah Kabupaten/Kota/Kecamatan/Pelaksan a distribusi.

e. Serah terima beras antara Perum Badan Urusan Logistik dengan Tim Koordinasi Subsidi beras bagi masyarakat berpendapatan rendah atau pelaksana distribusi dilakukan di titik distribusi dan dibuat berita acara serah terima yang ditandatangani oleh kedua belah pihak.

f. Pada prinsipnya penyaluran Subsidi beras bagi masyarakat berpendapatan rendah dilakukan setiap bulan. Jika terdapat kebijakan daerah dan atau kendalan antara lain musim panen, kondisi geografis, iklim atau cuaca, dan hambatan transportasi sehingga penyaluran subsidi beras tidak mungkin dilakukan secara rutin setiap bulan di suatu wilayah maka penyaluran subsidi beras dapat diatur lebih lanjut di dalam petunjuk pelaksana atau petunjuk teknis oleh pemerintah daerah setempat. 
Faktor-faktor yang mempengaruhi Efektivitas Sistem Pendistribusian Beras Bersubsidi untuk Masyarakat Berpen-dapatan Rendah dalam Meningkatkan Kesejahteraan Masyarakat di Kelurahan Talang Keramat Kabupaten Banyuasin

Menurut Makmur, (2011: 5) Efektivitas berhubungan dengan tingkat kebenaran atau keberhasilan dan kesalahan. Ia berpendapat bahwa untuk menentukan tingkat efektivitas keberhasilan seseorang, kelompok, organisasi bahkan sampai kepada negara kita harus melakukan perbandingan antara kebenaran dengan kekeliruan yang dilakukan. Semakin rendah tingkat kekeliruan atau kesalahan yang terjadi, tentunya akan semakin mendekati ketepatan dalam pelaksanaan setiap aktivitas atau pekerjaan (tugas) yang dibebankan setiap orang."

Menurut Makmur, (2011: 5) "terdapat faktor-faktor penghambat dan pendukung efektivitas dan kaitannya dengan penelitian tentang efektivitas sistem pendistribusian subsidi beras untuk masyarakat berpendapatan rendah adalah masih banyak kelemahan antara lain belum tepat sasaran, belum tepat jumlah dan belum tepat harga, hal ini jelas melanggar peraturan pemerintah dan mengurangi hak warga yang berhak menerimanya." Faktor penghambat dan pendukung efektivitas adalah sebagai berikut:

a. Faktor-faktor penghambat yang mempenga-ruhi efektivitas sistem distribusi subsidi beras untuk masyarakat berpendapatan rendah adalah sebagai berikut:

\section{Faktor Organisasi}

Faktor organisasi, untuk mengetahui sejauh mana faktor organisasi memberi-kan pengaruh terhadap efektivitas distribusi subsidi beras di Kelurahan Talang Keramat Kabupaten Banyuasin.

\section{Faktor Lingkungan}

Faktor lingkungan, untuk mengetahui sejauh mana lingkungan memberikan pengaruh terhadap efektivitas distribusi subsidi beras di Kelurahan Talang Keramat Kabupaten Banyuasin.Faktor Lingkungan meliputi lingkungan intern (masyarakat), lingkungan ekstern (pengelola subsidi beras) dan keberha-silan hubungan keduanya.

\section{Faktor Kinerja}

Faktor kinerja dilihat dari masyarakat yang kurang dilibatkan, pengelola subsidi berasatau pihak kelurahan yang dinilai belum menunjukkan kinerja yang maksimal dalam hal pendataan penerima subsidi beras untuk masyarakat berpendapatan rendah sehingga hasilnya juga cenderung kurang tepat sasaran, masih ada masyarakat yang tidak terdata Badan Pusat Statistik (BPS).

\section{Faktor Pekerja}

Faktor pekerja dilihat dari ketersediaan sumber daya manusia, perilaku Satuan Tugas (Satgas) dalam hal pendistribusian beras. Meskipun ketersediaan sumber daya manusia sudah memadai, masyarakat menilai masih ada individu dari satuan tugas(Satgas) subsidi beras yang belum menunjukkan kinerja yang maksimal. Disamping itu, masyarakat juga menilai satuan tugas (Satgas)subsidi beras masih ada yang pilih-pilih dalam hal pelayanan pendistribusian subsidi beras. 
b. Faktor-faktor pendukung yang mempenga-ruhi efektivitas sistem distribusi subsidi beras untuk masyarakat berpendapatan rendah adalah sebagai berikut:

\section{Faktor Fasilitas}

Fasilitas yang ada sudah memadai, seperti transportasi yang digunakan dalam mengambil beras ke kantor kelurahan dan tempat yang digunakan untuk meletakkan beras sebelum dibagi-kan kepada rumah tangga sasaran penerima manfaat.

\section{METODE PENELITIAN}

Dalam penelitian ini, peneliti menggunakan penelitian deskriptif kualitatif. Penelitian ini mengenai Efektivitas Sistem Pendistribusian Beras Bersubsidi untuk Masyarakat Berpendapatan Rendah dalam Meningkatkan Kesejahteraan Masyarakat di Kelurahan Talang Keramat Kabupaten Banyuasin dan dideskripsikan melalui temuan yang diperoleh melalui wawancara dengan warga dan observasi atau pengamatan.

\section{Definisi Konsep}

Menurut Singarimbun dan Efendi, (2008: 43) "Definisi konsep adalah pemaknaan dari konsep yang digunakan, sehingga memudahkan peneliti untuk mengoperasikan konsep tersebut di lapangan."

Untuk lebih jelas dalam mendefinisikan konsep Efektivitas Sistem Pendistribusian Subsidi Beras untuk Masyarakat Berpendapatan Rendah dalam Meningkatkan Kesejahteraan Masyarakat di Kelurahan Talang Keramat Kecamatan Talang Kelapa Kabupaten Banyuasin, maka peneliti uraikan sebagai berikut:

a. Efektivitas Sistem Pendistribusian Beras Bersubsidi untuk Masyarakat

\section{Faktor Manajemen}

Faktor kebijakan dan manajemen meliputi kebijakan, peranan pimpinan dan praktek manajemen.Proses mana-jemen Planning, Organizing, Actuating, Controlling(POAC) terlaksana dengan baik mulai dari Planning sampai Controlling terhadap proses penyaluran subsidi beras untuk masyarakat berpendapatan rendah.

Berpendapatan Rendah dalam meningkatkan Kesejahteraan Masyarakat di Kelurahan Talang Keramat Kecamatan Talang Kelapa Kabupaten Banyuasin merupakan ukuran dari pencapaian tujuan dalam bentuk target.

b. Kesejahteraan masyarakat atau kesejahteraan sosial dalam artian yang sangat luas mencakup berbagai tindakan yang dilakukan manusia untuk mencapai tingkat kehidupan masyarakat yang lebih baik di Kelurahan Talang Keramat Kabupaten Banyuasin. Tindakan yang dilakukan dalam hal ini adalah kebijakan Pemerintah untuk memenuhi kebutuhan pangan masyarakat dalam bentuk beras.

\section{Definisi Operasional}

Menurut Sugiyono, (2012: 31) "Definisi operasional adalah penentuan konstrak atau sifat yang akan dipelajari sehingga menjadi variabel yang dapat diukur. Definisi operasional menjelaskan cara tertentu yang digunakan untuk meneliti dan mengoperasikan konstrak, sehingga memungkinkan bagi peneliti yang lain untuk melakukan replikasi pengukuran dengan 
cara yang sama atau mengembangkan cara pengukuran konstrak yang lebih baik."
Adapun definisi operasional dalamskripsi ini yaitu dapat dilihat pada tabel berikut:

Tabel

Definisi Operasional

\begin{tabular}{|c|c|c|c|}
\hline No. & Konsep & Indikator & Sub Indikator \\
\hline 1. & $\begin{array}{l}\text { Efektivitas Sistem } \\
\text { Pendistribusian } \\
\text { Subsidi Beras untuk } \\
\text { Masyarakat } \\
\text { Berpendapatan } \\
\text { Rendah } \\
\text { (Peraturan Menteri } \\
\text { Koordinator } \\
\text { Pembangunan } \\
\text { Manusia dan } \\
\text { Kebudayaan Nomor } \\
1 \text { Tahun 2016 dalam } \\
\text { Pedoman Umum } \\
\text { Subsidi Beras) }\end{array}$ & $\begin{array}{l}\text { b. Tepat Waktu } \\
\text { c. Tepat Jumlah } \\
\text { d. Tepat } \\
\text { Administrasi }\end{array}$ & $\begin{array}{l}\text { Selain Fakir Miskin termasuk juga } \\
\text { lembaga sosial antara lain: Panti Sosial, } \\
\text { Rumah Singgah, Rumah Perlindungan } \\
\text { anak, Balai Rehabilitasi, Taman anak } \\
\text { sejahtera dan perempuan rawan sosial } \\
\text { ekonomi, masyarakat miskin akibat } \\
\text { bencana alam sampai dengan } 1 \text { tahun } \\
\text { setelah kejadian. } \\
\text { Waktu penyaluran subsidi beras adalah } \\
\text { 1x dalam } 1 \text { bulan. } \\
\text { Jumlah yang telah ditetapkan adalah } \\
\text { 15kg/Rumah Tangga Sasaran atau } \\
\text { 180kg/Tahun. } \\
\text { Syarat Administrasi terpenuhi secara } \\
\text { benar dan tepat waktu, contohnya } \\
\text { membawa Kartu Subsidi Beras ketika } \\
\text { mengambil beras dibalai kelurahan. } \\
\text { Harga Tebus Subsidi Beras yaitu sebesar } \\
\text { Rp. 1.600,-/Kg. } \\
\text { Kualitas Subsidi Beras yang di } \\
\text { distribusikan yaitu kualitas Medium } \\
\text { sesuai dengan Pedoman Umum Subsidi } \\
\text { Beras. }\end{array}$ \\
\hline 2. & $\begin{array}{l}\text { Kesejahteraan } \\
\text { Masyarakat } \\
\text { (Data Badan Pusat } \\
\text { Statistik Tahun 2016) }\end{array}$ & $\begin{array}{l}\text { b. Kesehatan } \\
\text { c. Pendidikan } \\
\text { d. Jumlah } \\
\text { Pengeluaran } \\
\text { e.Keadaan } \\
\text { tempat tinggal }\end{array}$ & $\begin{array}{l}\text { Pendapatan yang dimaksud dalam Keputusan } \\
\text { Menteri Sosial Nomor } 146 \text { Tahun } 2013 \text { yaitu } \\
\text { Mempunyai sumber mata pencaharian tetapi } \\
\text { tidak mempunyai kemampuan memenuhi } \\
\text { kebutuhan dasar } \\
\text { Tidak mampu atau mengalami kesulitan } \\
\text { untuk berobat ke tenaga medis kecuali ke } \\
\text { puskesmas atau yang disubsidi pemerintah. } \\
\text { Pendidikan tertinggi kepala rumah tangga } \\
\text { tidak sekolah atau tidak tamat SD atau tamat } \\
\text { SD. } \\
\text { Mempunyai pengeluaran sebagian besar } \\
\text { digunakan untuk memenuhi konsumsi } \\
\text { makanan pokok dengan sangat sederhana } \\
\text { Mempunyai dinding rumah terbuat dari } \\
\text { bamboo/kayu/tembok dengan kondisi }\end{array}$ \\
\hline
\end{tabular}




\begin{tabular}{|l|l|l|}
\hline $\mid$ & $\begin{array}{l}\text { tidak baik/kualitas rendah, termasuk } \\
\text { tembok yang sudah usang atau tidak } \\
\text { diplester }\end{array}$ \\
\hline
\end{tabular}

\section{Informan Penelitian}

Informan dapat disamakan dengan partisipan penelitian, yaitu subjek penelitian dimana dari mereka data penelitian dapat
diperoleh.Adapun informan penelitian dalam penelitian ini yaitu dapat dilihat pada tabel sebagai

Tabel

\section{Informan Penelitian}

\begin{tabular}{|c|c|c|}
\hline No. & Informan & Keterangan \\
\hline 1. & Lurah Talang Keramat & 1 Orang \\
\hline 2. & Sekretariat Kelurahan & 1 Orang \\
\hline 3. & Kasi Pelayanan Umum dan Sosial & 1 Orang \\
\hline 4. & Masyarakat Kelurahan Talang Keramat & 6 Orang \\
\hline \multicolumn{2}{r}{ TOTAL } & 9 Orang \\
\hline
\end{tabular}

\section{Teknik Pengumpulan Data}

Menurut Sugiyono, (2015: 62) "Teknik pengumpulan data merupakan langkah yang paling strategis dalam penelitian, karena tujuan utama dari penelitian adalah mendapatkan data. Tanpa mengetahui teknik pengumpulan data, maka peneliti tidak akan mendapatkan data yang memenuhi standar data yang ditetapkan."

Sesuai dengan penelitian kualitatif ini, maka teknik pengumpulan data yang digunakan dalam skripsi ini adalah sebagai berikut:

a. Observasi merupakan kegiatan pengamatan dan pencatatan yang dilakukan oleh peneliti terhadap objek penelitian guna menyempurnakan penelitian agar mencapai hasil yang maksimal.

b. Menurut Sugiyono, (2015: 72) "Wawancara merupakan pertemuan dua orang untuk bertukar informasi dan ide melalui tanya jawab, sehingga dapat dikonstruksikan makna dalam suatu topik tertentu." Wawancara digunakan sebagai teknik pengumpulan data apabila peneliti akan melaksanakan studi pendahuluan untuk menemukan permasalahan yang harus diteliti. Wawancara yang digunakan dalam penelitian ini adalah wawancara terstruktur yaitu pertanyaan disiapkan oleh peneliti.

c. Studi Pustaka adalah segala usaha yang dilakukan oleh peneliti untuk menghimpun informasi yang relevan dengan topik atau masalah yang akan atau sedang diteliti.

d. Dokementasi merupakan data yang diperoleh dalam bentuk dokumentasi yang sudah jadi seperti surat menyurat, arsip dan dokumen lain yang relevan dengan masalah penelitian ini dan dikumpulkan untuk 
menjadi dasar kesimpulan dari sebuah penelitian.

\section{Teknik Analisa Data}

Menurut Bogdan dalam Sugiyono, (2015: 88) "Pengertian Analisis Data adalah proses pencarian dan penyusunan data yang secara sistematis data yang diperoleh dari hasil wawancara, catatan lapangan, dan bahan-bahan lain sehingga dapat mudah dipahami dan temuannya dapat diinformasikan kepada orang lain. Analisis data dilakukan dengan mengorganisasikan data, menjabarkannnya ke dalam unit-unit , melakukan sintesa, menyusun ke dalam pola, memilih mana yang penting dan yang akan dipelajari, dan membuat kesimpulan yang dapat diceritakan kepada orang lain."

Teknik analisis data kualitatif yang dilakukan dalam penelitian ini sebagai berikut :

a. Reduksi

\section{HASIL PENELITIAN}

Peneliti akan mendeskripsikan hasil penelitian tentang Efektivitas Sistem Pendistribusian Beras Bersubsidi untuk Masyarakat Berpendapatan Rendah dalam Meningkatkan Kesejahteraan Masyarakat di Kelurahan Talang Keramat Kabupaten Banyuasin. Hasil penelitian ini diperoleh melalui teknik wawancara secara terstruktur dengan informan sebagai bentuk pencarian data dan dokumentasi langsung di tempat penelitian yang kemudian peneliti analisis.Penelitian ini menggunakan metode penelitian kualitatif untuk melihat kondisi alami dari suatu fenomena.

Selama melakukan observasi pada bulan Februari 2019, jumlah informan yang diwawancarai adalah sebanyak 9 orang. Informan yang diwawancarai adalah terdiri dari sebagai berikut:

a. Lurah Talang Keramat: 1 Orang
Melakukan Proses pengumpulan data melalui observasi, wawancara dan dokumentasi. Data yang didapat dari hasil penelitian kemudian memberikan interprestasi sehingga dapat menjelaskan dan menjawab yang diteliti.

b. Penyajian Data

Setiap data yang diperoleh dalam bentuk kategori kemudian melakukan penafsiran yang memberikan arti yang lebih luas dan penemuan penelitian, penyeleksian masingmasing data yang relevan dengan jelas.

c. Kesimpulan dan Verifikasi

Menarik kesimpulan serta melakukan pemahaman terhadap informasi yang didapat kemudian mancari makna dari gejala yang diperoleh dari lapangan, mencatat alur sebab dan akibat dan memberi solusi atas masalah yang diteliti.

b. Sekretaris Lurah: 1 Orang

c. Kasi Pelayanan Umum dan Sosial : 1 Orang

d. Masyarakat Kelurahan Talang Keramat: 6 Orang

Berdasarkan informasi dari informan diatas, maka peneliti akan memaparkan mengenai Efektivitas Sistem Pendistribusian Beras Bersubsidi untuk Masyarakat Berpendapatan Rendah dalam Meningkatkan Kesejahteraan Masyarakat di Kelurahan Talang Keramat Kabupaten Banyuasin yang dapat dilihat dalam beberapa indikator yaitu sebagai berikut:

Efektivitas Sistem Pendistribusian Beras Bersubsidi Untuk Masyarakat Berpendapatan Rendah (Berdasarkan Peraturan Menteri Koordinator Pembangunan Manusia dan Kebudayaan Nomor 1 Tahun 2016 dalam Pedoman Umum Subsidi Beras) 


\section{a. Tepat Sasaran}

Tepat Sasaran merupakan maksud dari terealisasinya suatu tujuan yaitu masyarakat yang terdaftar dalam daftar penerima manfaat subsidi beras yang berarti subsidi beras hanya diberikan kepada masyarakat berpendapatan rendah sesuai data Badan Pusat Statistik (BPS) Tahun 2016

\section{b. Tepat Waktu}

Tepat waktu merupakan waktu pelaksanaan distribusi beras kepada masyarakat berpendapatan rendah penerima manfaat sesuai dengan rencana distribusi yaitu satu bulan sekali.

\section{c. Tepat Jumlah}

Tepat jumlah merupakan jumlah beras dalam subsidi beras yang merupakan hak untuk masyarakat berpendapatan rendah penerima manfaat sesuai dengan ketentuan yang berlaku yaitu 15 kilogram/bulan atau 180 kilogram/tahun.

\section{d. Tepat Administrasi}

Tepat administrasi adalah terpenuhinya persyaratan administrasi secara benar, lengkap dan tepat waktu agar pelaksanaan distribusi dapat berjalan dengan benar dan tertib.

\section{e. Tepat Harga}

Tepat harga adalah harga tebus subsidi beras sampai ke titik distribusi harus sesuai dengan peraturan yang telah ditetapkan pemerintah yaitu Rp. 1.600,per kilogram atau Rp. 24.000,- dalam satu karung yang berisi 15 kilogram beras.

\section{f. Tepat Kualitas}

Tepat kualitas adalah terpenuhinya persyaratan kualitas beras sesuai dengan kualitas beras Badan Urusan Logistik (BULOG) yaitu beras dengan kualitas medium yang sudah melalui proses pengecekan oleh Tim Koordinasi Subsidi beras sebelum di distribusikan ke titik distribusi.

\subsubsection{Kesejahteraan Masyarakat (Berdasar-kan Data Badan Pusat Statistik Tahun 2016)}

\section{a. Pendapatan}

Pendapatan adalah pendapatan yang dimaksud dalam Keputusan Menteri Sosial Nomor 146 Tahun 2013 yaitu Mempunyai sumber mata pencaharian tetapi tidak mempunyai kemampuan memenuhi kebutuhan dasar.

\section{b. Kesehatan}

Kesehatan yang dimaksud adalah masyarakat yang tidak mampu atau mengalami kesulitan untuk berobat ke tenaga medis kecuali ke puskesmas atau yang disubsidi pemerintah.

\section{c. Pendidikan}

Pendidikan adalah kebutuhan dasar masyarakat agar dapat menjalani kehidupan dalam bermasya-rakat. Pendidikan yang dimaksud adalah tingkat pendidikan tertinggi kepala rumah tangga tidak sekolah atau tidak tamat SD atau hanya sampai tamat SD.

\section{d. Jumlah Pengeluaran}

Jumlah pengeluaran adalah masyarakat yang mempunyai pengeluaran sebagian besar digunakan untuk memenuhi konsumsi makanan pokok dengan sangat sederhana.

\section{e. Keadaan tempat tinggal}

Keadaan tempat tinggal adalah kondisi rumah warga yang mempunyai dinding rumah terbuat dari bamboo/kayu atau tembok dengan kondisi tidak baik atau kualitas rendah, termasuk tembok yang sudah usang atau tidak diplester

Faktor-faktor penghambat dan pendukung yang mempengaruhi Efektivitas Sistem Pendis-tribusian Subsisi Beras di Kelurahan Talang Keramat Kecamatan Talang Kelapa Kabupaten Banyuasin antara lain sebagai berikut: 
a. Faktor Pendukung Efektivitas Sistem Pendistribusian Subsidi beras antara lain sebagai berikut:

1. Faktor Organisasi

2. Faktor Lingkungan

3. Faktor Kinerja

4. Faktor Pekerja

b. Faktor Penghambat Efektivitas Sistem Pendistribusian Subsidi beras antara lain sebagai berikut:

1. Faktor Fasilitas

2. Faktor Manajemen

Berikut ini merupakan pembahasan mengenai Efektivitas Sistem Pendistribusian Beras Bersubsidi Untuk Masyarakat Berpendapatan Rendah dalam Meningkatkan Kesejahteraan Masyarakat di Kelurahan Talang Keramat Kabupaten Banyuasin. Peneliti melakukan dua konsep yaitu Efektivitas Sistem Pendistribusian dan Kesejahteraan Masyara-kat dapat dijelaskan sebagai berikut:

\section{Efektivitas Sistem Pendistribusian Beras Bersubsidi Untuk Masyarakat Berpenda-patan Rendah}

Pembahasan mengenai Efektivitas Sistem Pendistribusian Beras Bersubsidi Untuk Masyarakat Berpendapatan Rendah dalam Meningkatkan Kesejahteraan Masyarakat di Kelurahan Talang Keramat Kabupaten Banyuasin penulis uraikan sebagai berikut:

\section{A. Efektivitas Sistem Pendistribusian Beras Bersubsidi}

Dalam konsep ini penulis berpedoman pada Peraturan Menteri Koordinator Bidang Pembangunan Manusia dan Kebudayaan Republik Indonesia Nomor 1 Tahun 2016 Tentang Pedoman Umum Subsidi Beras Untuk Masyarakat Berpendapatan Rendah yang mempunyai enam indikator yaitu Tepat sasaran, Tepat waktu, Tepat Jumlah, Tepat Administrasi, Tepat harga, dan Tepat
Kualitas. Berikut ini pembahasan mengenai indikator-indikator tersebut.

\section{Tepat Sasaran}

Sasaran penerima manfaat merupakan aspek utama dalam subsidi beras, sasaran tersebut adalah warga yang menurut kriteria Badan Pusat Statistik (BPS) adalah tergolong masyarakat berpendapatan rendah.Tepat sasaran yang dimaksud adalah sebagai berikut:

1. Mereka yang berpendapatan rendah, termasuklah rumah perlindungan anak.

2. Panti Sosial.

3. Perempuan rawan sosial ekonomi.

4. Masyarakat yang miskin akibat dari bencana alam sampai dengan satu tahun setelah kejadian.

Sasaran penerima manfaat subsidi beras di Kelurahan Talang Keramat belum terealisasi dengan baikkarena harus berbagi dengan warga yang belum terdaftar, dan juga kalau ditinjau dari kalimat "untuk masyarakat berpendapatan rendah" belum sampai maknanya ke warga penerima manfaat subsidi beras. Mereka yang jelas-jelas tidak terdaftar berarti tergolong bukan masyarakat berpendapatan rendah dan juga kemungkinan identitas kependudukannya adalah masih data tempat tinggal lama belum mengurus laporan pindah di Kelurahan, sehingga dianggap bukan warga Kelurahan Talang Keramat.

\section{Tepat Waktu}

Waktu penyaluran subsidi beras berhubungan dengan distribusi beras yang sampai di titik distribusi, waktu distribusi beras dari Badan Urusan Logistik (BULOG) adalah 1 kali dalam 1 bulan.Jangka waktu penyaluran subsidi beras menjadi harapan setiap masyarakat Indonesia, begitu pula dengan penyaluran subsidi beras yang berjalan 
di Kelurahan Talang Keramat Kabupaten Banyuasin.Penyaluran subsidi beras di Kelurahan Talang Keramat waktunya tidak menentu, harusnya satu bulan sekali namun menunggu hingga 2 sampai 3 bulan sekali baru mendapatkan subsidi beras.

\section{Tepat Jumlah}

Jumlah subsidi beras yang dikirim dari Badan Urusan Logistik (BULOG) adalah 1 karung dengan berat 15 kilogram untuk masing-masing kepala keluarga. Jumlah subsidi beras menjadi permasalahan ketika sampai di titik distribusi, sama halnya dengan jumlah subsidi beras yang berjalan di Kelurahan Talang Keramat Kabupaten Banyuasin. Jumlah subsidi beras prakteknya di lapangan ketika subsidi beras sudah dikoordinasi oleh ketua Rukun Tetangga, beras tersebut sudah dibuka karungannnya dan ada juga yang sudah ditimbang dengan jumlah yang sama rata karena ketua RT mengukur tingkat kemampuan warganya untuk menebus beras dan menghindari kecemburuan warga yang belum terdaftar agar bisa mendapatkan subsidi beras. Hal ini bertolak belakang dengan tujuan pemerintah yaitu membantu masyarakat memenuhi kebutuhan pangan dalam bentuk beras.Indikator tepat jumlah dikatakan kurang efektif dan harus dilakukannya penegasan dari kelurahan kepada setiap ketua RT.

\section{Tepat Administrasi}

Syarat Administrasi untuk pengambilan subsidi beras harus terpenuhi secara benar syarat tersebut adalah fotocopi kartu keluarga dan kartu pengambilan subsidi beras. Syarat administrasi yang ada di kelurahan Talang Keramat sudah berjalan dengan benar dan sesuai aturan.Warga yang keterbatasan waktu dan kendaraan untuk mengambil subsidi beras di rumah ketua RT bisa menitipkan fotocopi kartu keluarga dan kartu pengambilan subsidi berasnya untuk diwakili oleh tetangganya. Hal ini dikarenakan untuk mempercepat proses distribusi beras agar bisa cepat sampai ketangan rumah tangga sasaran dan agar cepat juga menyetorkan uang subsidi beras ke rekening Badan Urusan Logistik (BULOG) dengan harapan dibulan selanjutnya subsidi beras bisa lancar distribusinya ke Kelurahan Talang Keramat Kabupaten Banyuasin.

Syarat administrasi yang tergolong tidak rumit ini menjadikan indikator tepat administrasi dikatakan sudah efektif dan harapan kedepannya agar dapat dipertahankan dan lebih ditingkatkan lagi budaya tertib administrasinya.

\section{Tepat Harga}

Harga tebus subsidi beras berdasarkan Peraturan Menteri Koordinator Bidang Pembangunan Manusia dan Kebudayaan Republik Indonesia Nomor 1 Tahun 2016 Tentang Pedoman Umum Subsidi Beras Untuk Masyarakat Berpendapatan Rendah bahwa harga tebus subsidi beras adalah sebesar Rp. 1.600,- per kilogram. Harga tebus subsidi beras di Kelurahan Talang Keramat hampir 50\% naik dari harga tebus yang telah ditetapkan, kenyataan yang terjadi harga tebusnya adalah Rp. 3000,- per kilogram.

Kenaikan harga tebus beras yang drastis ini membuat warga merasa resah dan memperbin-cangkannya di lingkungan masyarakat hanya saja karena harga tebus yang masih tergolong murah membuat mereka tidak banyak protes, warga menerima saja dengan harga tebus Rp. 3000,- tersebut. Harga tebus yang melonjak naik ini akibat dari jumlah beras yang awalnya 15 kilogram 
dibuka karungannya dan dimasukan kedalam plastik lain yang membuat ketua RT memperhitungkan harga plastik, jasa angkut dan upah timbang. Seharusnya hal ini tidak diberlakukan seperti itu karena membebankan warga walaupun nominal harganya masih terjangkau.

Harga tebus beras yang dua kali lipat dari harga tebus sebelumnya menjadikan Indikator tepat harga di Kelurahan Talang Keramat Kabupaten Banyuasin dikatakan kurang efektif, harus dilakukan perbaikan terhadap harga tebus beras dan harus melakukan realisasi harga tebus sesuai dengan Peraturan Menteri Koordinator Bidang Pembangunan Manusia dan Kebudayaan Republik Indonesia Nomor 1 Tahun 2016 Tentang Pedoman Umum Subsidi Beras Untuk Masyarakat Berpendapatan Rendah yaitu sesuai dengan tujuan Pemerintah untuk mengurangi beban pengeluaran masyarakat bukan membebani masyarakat.

\section{Tepat Kualitas}

Membahas tentang kualitas subsidi beras tidak ada habisnya dan selalu jadi berita dimana-mana.Kualitas beras yang dikirim Badan Urusan Logistik (BULOG) adalah beras kualitas medium yang layak konsumsi, sebelum beras didistribusikan ke kelurahan pihak satuan tugas Badan Urusan Logistik (BULOG) telah melakukan pengecekan kualitas.Warga kelurahan Talang Keramat yang merupakan warga penerima manfaat sengaja mencampur beras subsidi dengan beras bagus untuk dikonsumsi dengan alasan agar beras yang dimasak terlihat putih sehingga citra dari kualitas beras ini menjadi buruk.

$$
\text { Sebenarnya beras yang }
$$

didistribusikan oleh pemerintah sudah layak konsumsi dan tidak menganggu kesehatan karena sudah melalui proses pengecekan oleh Tim Koordinasi Badan Urusan Logistik (BULOG). Seharusnya warga tidak perlu mencampur beras subsidi dengan beras bagus, hal ini justru menambah pengeluaran.Kualitas beras yang dikirim Badan Urusan Logistik (BULOG) cukup dibersihkan padinya dan dicuci bersih sebelum dimasak, hanya saja mungkin dalam satu karung sekitar 500gram merupakan padi.Warga hanya butuh kesabaran ketika membersihkan beras dan bukan berarti beras tidak layak konsumsi.

Indikator tepat kualitas dikatakan cukup efektif, karena dari pemerintah dan dari Badan Urusan Logistik (BULOG) sudah memberikan kualitas beras yang medium atau layak konsumsi, tetapi warga menajdikan citra subsidi beras menjadi buruk.Penulis berharap citra kualitas beras tidak dijadikan buruk karena bantuan beras dari Pemerintah merupakan wujud dari pedulinya pemerintah terhadap seluruh masyarakatnya.

Aparat kelurahan dan ketua RT di Kelurahan Talang Keramat Kabupaten Banyuasin tidak menjalankan distribusi beras dengan baik dan dapat dikatakan kurang efektif karena tujuan dan ukuran dari efektivitas adalah tercapainya tujuan dengan baik.

Pelaksanaan Efektivitas Sistem Pendistri-busian Beras Bersubsidi Untuk Masyarakat Berpendapatan Rendah di Kelurahan Talang Keramat Kabupaten Banyuasin dikatakan kurang efektif karena sasaran atau tujuan dari efektivitas sistem pendistribusian beras bersubsidi yang diperuntukan untuk masyarakat berpendapatan rendah belum terealisasi dengan baik dan belum berjalan seperti ketentuan yang telah ditetapkan pemerintah sehingga masih 
membutuhkan pembenahan dan sosialisasi dari aparat kelurarahan agar semuanya dapat berjalan dengan benar dan sesuai dengan aturan pemerintah.

\section{Meningkatkan \\ Kesejahteraan \\ Masyarakat di Kelurahan Talang Keramat Kabupaten Banyuasin}

Pembahasan mengenai Meningkatkan Kesejahteraan Masyarakat di Kelurahan Talang Keramat Kabupaten Banyuasin peneliti uraikan sebagai berikut:

\section{A. Kesejahteraan Masyarakat}

Dalam konsep ini penulis berpedoman pada Kriteria Badan Pusat Statistik (BPS) tahun 2016 yang mempunyai lima indikator yaitu pendapatan, kesehatan, pendidikan, jumlah pengeluaran dan keadaan tempat tinggal. Berikut ini pembahasan mengenai indikator-indikator tersebut.

\section{Pendapatan}

Pendapatan merupakan ukuran dan kriteria pertama Badan Pusat Statistik (BPS) dalam mendata warga untuk memperoleh subsidi beras.Pendapatan warga yang tergolong rendah, membeli beras subsidi dengan harga murah menjadi nilai tersendiri bagi masyarakat tersebut.Setidaknya dapat mengurangi beban pengeluaran dalam bentuk beras.

\section{Kesehatan}

Kesehatan merupakankondisi jasmani dan rohani masyarakat, masyarakat yang sehat jasmani dan rohani akan mampu menjalankan kegiatan dengan baik. Masyarakat yang berpendapatan rendah membuat masyarakat tersebut terbebani dengan biaya pengobatan, bantuan-bantuan dari pemerintah menjadi harapan masyarakat dalam menjalani kehidupan seharihari.Kesehatan merupakan kriteria yang ditetapkan oleh Badan Pusat Statistik (BPS) untuk mengukur kemiskinan.

\section{Pendidikan}

Pendidikan merupakan hal yang paling penting bagi masyarakat untuk bisamendapatkan pekerjaan yang layak dan penghasilan yang sesuai. Kriteria Badan Pusat Statistik (BPS) pada indikator pendidikan adalah pendidikan tertinggi kepala rumah tangga yaitu tidak sekolah atau tidak tamat SD atau tamat SD. Pendidikan kepala rumah tangga di Kelurahan Talang Keramat Kabupaten Banyuasin sebagian besar tergolong rendah atau hanya tamat SD dan juga untuk masyarakat yang tamat SMA sederajat saja sulit mendapatkan pekerjaan sehingga membuat mereka mengandalkan tenaga untuk mendapatkan penghasilan. Subsidi beras dari Pemerintah diperuntukkan untuk masyarakat berpendapatan rendah termasuklah masyarakat yang pendidikannya rendah dan penghasilan yang kurang mencukupi.

\section{Jumlah Pengeluaran}

Jumlah pengeluaran adalah biayabiaya yang dikeluarkan masyarakat dalam pemenuhan kebutuhan rumah tangga. Jumlah pengeluaran menurut kriteria Badan Pusat Statistik (BPS) adalah pengeluaran yang sebagian besar digunakan untuk memenuhi konsumsi makanan pokok dengan sangat sederhana. Jumlah pengeluaran masyarakat di Kelurahan Talang Keramat Kabupaten Banyuasin sebagian besar adalah untuk membeli kebutuhan pangan yang tergolong sederhana, untuk membeli lauk seperti daging dan ayam membuat mereka merasa terbebani karena penghasilannya digunakanuntuk kebutuhan yang lain seperti bayar listrik, kebutuhan rumah tangga, ongkos sekolah dan lain sebagainya.

\section{Keadaan tempat tinggal}

Keadaan tempat tinggal
merupakan wujud dari rendahnya


pendapatan seseorang. Menurut kriteria Badan Pusat Statistik (BPS) tahun 2016 adalah keadaan tempat tinggal yang dinding rumah terbuat dari bamboo/kayu atau tembok dengan kondisi tidak baik atau kualitas rendah, termasuk tembok yang sudah usang atau tidak diplester. Keluarga seperti ini merupakan keluarga yang menurut kemampuan ekonominya lemah atau rendah, mereka miskin kepeduliannya untuk mengubah hidupnya menjadi lebih baik, misalnya demi pendidikan dan kesehatan mereka membiarkan rumahnya masih berlantai dengan tanah padahal sebenarnya sudah mampu namun lebih mementingkan kepentingan pangan, pendidikan dan kesehatan daripada memperbaiki rumah atau kalau ada anak yang sakit tidak langsung dibawa ke dokter namun diperiksa saja dulu dipuskesmas karena ekonomi yang sulit.

Indikator-indikator dari kesejahteraan sosial yang meliputi pendapatan, kesehatan, pendidikan, jumlah pengeluaran, dan keadaan tempat tinggal yang berhubungan dengan subsidi beras realitanya subsidi beras yang berjalan di Kelurahan Talang Keramat Kabupaten Banyuasin hanya mampu membantu biaya pengeluaran dalam bentuk beras tetapi belum mampu meningkatkan kesejahteraan masyarakat di Kelurahan Talang Keramat Kabupaten Banyuasin.

Faktor-faktor yang mempengaruhi Efektivitas Sistem Pendistribusian Beras Bersubsidi untuk Masyarakat Berpendapatan Rendah di Kelurahan Talang Keramat Kabupaten Banyuasin

Di bawah ini penulis menjabarkan faktor-faktor yang mempengaruhi efektivitas, yang dikemukakan oleh Makmur, (2011: 5).Ia berpendapat bahwa untuk menentukan tingkat efektivitas keberhasilan seseorang, kelompok, organisasi bahkan sampai kepada negara kita harus melakukan perbandingan antara kebena-ran dengan kekeliruan yang dilakukan. Semakin rendah tingkat kekeliruan atau kesalahan yang terjadi, tentunya akan semakin mendekati ketepatan dalam pelaksanaan setiap aktivitas atau pekerjaan (tugas) yang dibebankan setiap orang.

Berikut faktor-faktor yang mempengaruhi efektivitas sistem pendistribusian beras bersubsidi untuk masyarakat berpendapatan rendah dalam meningkatkan kesejahteraan masyarakat di kelurahan Talang Keramat Kabupaten Banyuasin diantaranya sebagai berikut:

a. Faktor-faktor penghambat yang mempe-ngaruhi efektivitas sistem distribusi subsidi beras untuk masyarakat berpen-dapatan rendah adalah sebagai berikut:

\section{Faktor Organisasi}

Faktor organisasi, untuk mengetahui sejauh mana faktor organisasi memberikan pengaruh terhadap efektivitas distribusi subsidi beras di Kelurahan Talang Keramat Kabupaten Banyuasin.Dalam hal ini dilihat dari struktur organisasi kelurahan yang dinilai kurang berjalan dengan maksimal dikarenakan masih adanya pihak yang tidak dilibatkan, dimana pihak tersebut seharusnya dilibatkan guna lebih mendukung efektivitas penyaluran subsidi beras untuk masyarakat berpendapatan rendah agar berjalan lebih baik.

\section{Faktor Lingkungan}

Faktor lingkungan, untuk mengetahui sejauh mana lingkungan memberikan pengaruh terhadap efektivitas distribusi 
subsidi beras di Kelurahan Talang

Keramat

Kabupaten

Banyuasin.Faktor Lingkungan

meliputi lingkungan intern

(masyarakat), lingkungan ekstern (penge-lola subsidi beras) dan keberha-silan hubungan keduanya.

\section{Faktor Kinerja}

Faktor kinerja dilihat dari masyarakat yang kurang dilibatkan, pengelola subsidi berasatau pihak kelurahan yang dinilai belum menunjukkan kinerja yang maksimal dalam hal pendataan penerima subsidi beras untuk masyarakat berpendapatan rendah sehingga hasilnya juga cenderung kurang tepat sasaran, masih ada masyarakat yang tidak terdata Badan Pusat Statistik (BPS).

\section{Faktor Pekerja}

Faktor pekerja dilihat dari ketersediaan sumber daya manusia, perilaku Satuan Tugas (Satgas) dalam hal pendistri-busian beras. Meskipun ketersediaan sumber daya manusia sudah memadai, masyarakat menilai masih ada individu dari satuan tugas(Satgas) subsidi beras yang belum menunjukkan kinerja yang maksimal. Disamping itu, masyarakat juga menilai satuan tugas (Satgas)subsidi beras masih ada yang pilih-pilih dalam hal pelayanan pendistribusian subsidi beras.

b. Faktor-faktor pendukung yang mempeng-aruhi efektivitas sistem distribusi subsidi beras untuk masyarakat berpen-dapatan rendah adalah sebagai berikut:

\section{Faktor Fasilitas}

Fasilitas yang ada sudah memadai, seperti transportasi yang digunakan dalam mengambil beras ke kantor kelurahan dan tempat yang digunakan untuk meletakkan beras sebelum dibagikan kepada rumah tangga sasaran penerima manfaat.

\section{Faktor Manajemen}

Faktor kebijakan dan manajemen meliputi kebijakan, peranan pimpinan dan praktek manajemen.Proses manajemen Planning, Organizing, Actuating, Controlling(POAC) terlaksana dengan baik mulai dari Planning sampai Controlling terhadap proses penyaluran subsidi beras untuk masyarakat berpendapatan rendah.

Upaya Pemerintah Kelurahan Talang Keramat dalam meningkatkan Efektivitas Sistem Pendistribusian Beras Bersubsidi di Kelurahan Talang Keramat Kabupaten Banyuasin

Dari hasil penelitian peneliti dan berdasarkan observasi di Kelurahan Talang Keramat Kabupaten Banyuasin, ternyata dapat simpulkan bahwa pemerintah Kelurahan Talang Keramat Kabupaten Banyuasin belum mampumeningkatkan efektivitas pendistribusian yang ada.Ketika di wawancara oleh penulis sendiri, pihak kelurahan hanya mampu menjalankan mekanisme yang ada, tanpa mampu mencari inovasi maupun solusi untuk meningkatkan pendistribusian subsidi beras tersebut.

Sangat disayangkan sekali ternyata pihak kelurahan Talang Keramat ternyata belum mampu berupaya meningkatkan efektivitas sistem pendistribusian subsidi beras, padahal kelurahan merupakan 
instansi pemerintah yang cukup dekat dengan rumah tangga miskin atau masyarakat berpendapatan rendah.Keberadaan-nya di harapkan mampu memberikan kontribusi yang positif terhadap warga yang berpendapatan rendah yang ada di kelurahan Talang Keramat.Namun harapan itu belum bisa di realisasikan dengan baik karena masih diperlukan sosialisasi antara aparat kelurahan dengan masyarakat.

\section{KESIMPULAN}

Berdasarkan hasil penelitian yang peneliti lakukan, maka peneliti menarik simpulan sebagai berikut :

1. Efektivitas Sistem Pendistribusian Beras Bersubsidi Untuk Masyarakat Berpendapatan Rendah di Kelurahan Talang Keramat Kabupaten Banyuasin belum berjalan seperti yang diharapkan, hal ini dikarenakan indikator keberhasilan subsidi beras 6T, yaitu : tepat sasaran, tepat waktu, tepat jumlah, tepat administrasi, tepat harga, dan tepat kualitas yang belum sepenuhnya tercapai sehingga bisa dikatakan kurang efektif. Kendala tersebut antara lain karena cara berfikir masyarakat yang sempit akibat pengaruh lingkungan yang kurang kondusif dan kurangnya sosialisasi dari aparat kelurahan mengenai subsidi beras, serta adanya faktor-faktor yang mempengaruhi efektivitas sistem pendistribusian subsidi beras antara lain faktor organisasi, faktor lingkungan, faktor kinerja, faktor pekerja, faktor fasilitas, dan faktor manajemen.

2. Beras bersubsidi dari pemerintah yang berjalan di Kelurahan Talang Keramat Kecamatan Talang Kelapa Kabupaten Banyuasin hanya mampu membantu sedikit biaya pengeluaran masyarakat berpenda-patan rendah dan belum mampu meningkatkan kesejahteraan untuk pemenuhan kebutuhan dalam bentuk beras akibat dari kurang efektifnya subsidi beras yang berjalan di Kelurahan Talang Keramat Kecamatan Talang Kelapa Kabupaten Banyuasin.

\section{DAFTAR PUSTAKA}

Abdurahmat, 2008. Efektivitas Organisasi. Jakarta: Airlangga.

Adi, Fahrudin, 2012. Pengantar Kesejahteraan Sosial. Bandung: PT. Refika Aditama.

Alma, Buchari, 2007. Manajemen Pemasaran. Bandung: Alfabeta.

Bungin, Burhan, 2003. Analisis Data Penelitian Kualitatif. Jakarta: PT. Raja Grafindo Persada.

Komorotomo, Wahyudi, 2003. Etika Adminis-trasi Negara. Jakarta: Rajawali Pers.

Kotler, 2010.Manajemen Pemasaran, (online),

(http://pengertian.blogspot.co.id diakses pada 18 Desember 2018.

Makmur, 2011.Efektivitas Kebijakan Kelembagaan Pengawasan. Bandung: Refika Aditama.

Moenir, H.A.S, 2006. Manajemen Pelayanan Umum di Indonesia. Jakarta: Bumi Aksara.

Pedoman umum Raskin Tahun 2016 tentang Mekanisme Penyaluran Beras Bersubsidi Untuk Masyarakat Berpendapatan

Rendah.(Online),(http://www.kemenk opmk.go.id diakses pada 16 November 2017).

Sedarmayanti, 2009.Sumber Daya Manusia dan Produktivitas Kerja. Bandung: CV.Mandar Maju. 
Singarimbun,

Sofian

effendi,

2008. Metode

Penelitian

Survei.

Jakarta: LP3S.

Sugiyono, 2003.Metode Penelitian Administrasi. Bandung: Alfabeta.

2015. Memahami Penelitian Kualitatif. Bandung: Alfabeta.

Supranoto, 2013.Implementasi Kebijakan Pemanfaatan Alokasi Dana Desa. Jurnal Ilmu Administrasi Negara, 12(2) : 94.

Supriyono, 2009.Pengertian Efektivitas, (Online), (http://elib.unikom.ac.id diakses pada 09 Desember 2017).

Susanto, Azhar, 2013. Pengertian Sistem,

(Online), (http://elib.unikom.ac.id diakses pada 10 Desember 2017).

Sutarman, 2009.Pengantar Teknologi Informasi. Jakarta: Bumi Aksara.

Tjiptono, Fandi, 2008. Stategi Pemasaran. Jogjakarta: Andi.

Todaro dkk, 2006.Kesejahteraan Sosial, (Online),(http://erepo.unud.ac.id diakses pada 10 Desember 2017).

Undang-Undang Dasar Negara Republik Indonesia Nomor 11 Tahun 2009 tentang Kesejahteraan Sosial.

(Online),(http://puuonline.blogspot.co.id /2016/04 diakses pada 10 November 2017). 